\title{
Risks and Controls in the Implementation of ERP Systems
}

\author{
Severin V. Grabski. Michigan State University, U.S.A. \\ grabski@pilot.msu.edu
}

Stewart A. Leech. The University of Melbourne, Australia saleech@unimelb.edu.au

\author{
Bai Lu. Colonial Mutual Group, Australia \\ blu@colonial.com.au
}

\begin{abstract}
The implementation of ERP systems has been problematic for many organizations. Given the many reports of substantial failures, the implementation of packaged ERP software and associated changes in business processes has proved not to be an easy task. As many organizations have discovered, the implementation of ERP systems can be a monumental disaster unless the process is handled carefully.

The aim of this study is to identify the risks and controls used in ERP implementations, with the objective to understand the ways in which organizations can minimize the business risks involved. By controlling and minimizing the major business risks in the first instance, the scene can be set for the successful implementation of an ERP system. The study was motivated by the significance, for both the research and practice communities, of understanding the risks and controls critical for the successful implementation of ERP systems.

Following the development of a model of risks and controls, a field study of an ERP system implementation project in an organization was conducted to provide a limited test of the model. The results from the field study provided support for risks and controls identified in the literature. The results also identified several controls not mentioned in the reviewed literature. The study lays the foundation for further research into the risk/control framework so important for the success of the implementations of ERP systems.
\end{abstract}

Key Words: ERP Systems, Business Risks, Controls 


\section{INTRODUCTION}

The ready availability of sophisticated enterprise resource planning (ERP) software (such as SAP, JDE, PeopleSoft, Oracle, BAAN) has eventually delivered the dream of the proponents of data base management systems from the 1970s and 1980s. However, the dream has been shattered in many instances because of lack of success in implementing the software in organizations. Headlines such as "SAP:Whirlpool's Rush To Go Live Led To Shipping Snafus" (Collett, 1999), "GoreTex Maker Files Suit Over Software Installation" (McGeever, 1999), "Delays, Bugs, and Cost Overruns Plague PeopleSoft's Services" (Olsen, 1999) "ERP Project Leads to Court Fight" (Stedman, 1999) and "PeopleSoft Problems Persist, Cleveland State Looks for a New Project Manager" (Olsen, 2000) are indicative that ERP implementations can be difficult. In 1995 alone, U.S. firms spent an estimate $\$ 59$ million in cost overruns on information systems projects and another $\$ 81$ million on cancelled software projects (Johnson, 1995). Furthermore, it is estimated that approximately 90 percent of ERP implementations are late or over budget (Martin, 1998).

ERP implementations are different from "traditional" systems analysis and design projects (Davenport, 2000). Among the significant differences are the scale, complexity, organizational impact, and the costs of ERP projects and subsequent business impact if the project does not succeed. An ERP implementation will impact the entire organization, whereas a traditional project impacts often only a limited area of the organization. Furthermore, ERP projects are almost always associated with the reengineering of business practices. This results from the desire to adopt the "best practices" inherent in the chosen software solution rather than changing the software to match current business practices. Historically, traditional analysis and design projects had no (or minimal) reengineering and the software was written to match current practices. Additionally, an ERP implementation most always requires personnel to learn new programming languages and may also result in a shift in on organization's computing paradigm, from mainframe-based to network-centric. Finally, the cost of ERP projects is significantly higher than traditional projects, and failure can result in the demise of the organization (for example, the FoxMeyer Drugs bankruptcy (Scott, 1999)).

The aim of this study is to identify the risks and controls used in ERP implementations, with the objective to understand the ways organizations can minimize the business risks involved. Audit firms minimize the risk of an audit failure through the identification of the inherent risk, control risk and detection risk within that setting followed by the establishment of an acceptable and specified level of overall audit risk that is a function of those other risks (Arens and Loebbecke, 1997). We argue that the same rational can be applied to the implementation of ERP systems. By controlling and minimizing the major business 
risks in the first instance, the scene can be set for the successful implementation of an ERP system. The study was motivated by the significance, for both the research and practice communities, of understanding the risks and controls critical for the successful implementation of ERP systems and the scarcity of this particular approach in the literature. The paper proceeds as follows. In the next section, we identify the business risks associated with systems implementations from both the ERP literature and the traditional systems analysis and design literature. Section III examines each of the risks in more detail and identifies the controls that can be utilized to minimize each risk. A model of risks and associated controls is developed in this section. In Section IV, we present a case study of the controls put in place by a specific organization for the successful implementation of an ERP system. Section V presents the results from the case study. A number of controls not previously identified or emphasized in the literature were discovered in the case study. Finally, concluding thoughts, limitations and ideas for future research are presented.

\section{ERP IMPLEMENTATION BUSINESS RISKS}

The identification of risks in information systems projects has been the subject of much research (Jiang et al., 1996; Zmud, 1980). A portfolio approach for managing software development risk was discussed by McFarlan (1981). Prior research has looked at risk from a technological perspective (Anderson and Narasumhan, 1979) or from a software development perspective (Barki, et al. 1993). Jiang and Klein (1999) examined risk as it related to a multidimensional concept of information success that included satisfaction with the development process, satisfaction with system use, satisfaction with system quality, and the impact of the information system on the organization. In their study project managers were asked about problems on a recently completed information systems project. The risks associated with the overall success of a systems project were application complexity, lack of user experience, and lack of role clarity of role definitions of individuals on the project. Lack of user support was significant for the organizational impact, while technological newness affected system quality satisfaction. Systems development was affected by the team's general expertise, application complexity and user experience, and systems use was affected by role clarity and user experience. Reel (1999) discussed the importance of understanding user needs and mitigating user resistance, proper project management including project scope definition, top management sponsorship, and having a project team that possesses the appropriate skills. While these prior studies are relevant, none explicitly examined the environment of ERP systems. In these studies, the risks and controls were more technological focussing on software development as compared to the implementation of packaged solutions that require the reengineering of business processes and limited software modifications. 
In order to maximize the probability of success, the risks associated with a task must be minimized (Barki, et al. 1993; Jiang and Klein, 1999). As stated above, audit firms minimize the risk of audit failure through the identification of inherent, control and detection risks followed by the establishment of an acceptable, specified level of overall audit risk that is a function of those other risks (Arens and Loebbecke, 1997). The same rationale holds for the implementation of an ERP system. In order to maximize the probability of success, the risks must be identified and appropriate controls put in place to minimize those risks.

The lack of alignment between the organization strategy, structure, and processes and the chosen ERP application is one risk that is repeatedly identified in the literature is (see, for example, (Davenport, 1998; 2000)). Both the business process reengineering literature (Hammer, 1990; Hammer and Champy, 1993) and the ERP literature suggests that an ERP system alone cannot improve the company performance unless an organization restructures its operational processes (Bingi et al., 1999; Davenport, 1998; Davenport, 2000). Further, the ERP implementation project must be a business initiative. This requires the organization to gain strategic clarity (i.e., know the business, how it delivers value, etc.) and a constancy of purpose. Finally, an outcomes orientation is required to achieve these goals.

Within an ERP project, the loss of control over the project is another major risk. Loss of control can arise in at least two ways: the lack of control over the project team, and the lack of control over employees once the system is operational. Risks associated with controlling major projects existed prior to the development of ERP software, and much has been written on project escalation (see, for example, Brockner, 1992; Kanodia et al., 1989; Keil, 1995; Sharp and Salter, 1997; Staw, 1976; 1981; Staw and Ross, 1987). The first risk is the lack of control over the project team. This lack of control results from the decentralization of decision-making and subsequent ineffective ratification of decisions. Within the setting of an ERP project, in order to ensure the collocation of knowledge with decision rights, it is common for an organization to form an ERP system implementation project team that involves individuals who have some relevant specific knowledge associated with the implementation of an ERP system (such as information technology knowledge or change management skills). Decision rights are then assigned to the team. However, where the project team has complete control over the ratification of its own decisions creates a potential business risk that the project team would act in their own interests rather than act in the best interests of the organization. The second risk is that an operational ERP system most always results in the devolution of responsibility and empowerment of lower level employees. A lack of adequate controls over 
this increased responsibility, either within the ERP system itself or in the processes followed by the organization, is a potential business risk.

Another major risk is project complexity (see, for example, Barki, et al. 1993). An ERP system implementation involves relatively large expenditures for the acquisition of the hardware, software, implementation costs, consulting fees and training costs (Davenport, 2000; Mckie, 1998), and can last for an extended period of time. Also, an ERP system implementation project has a wider scope compared to most other information system implementations, and may cause a significant number of changes within an organization (Davenport, 2000). The scope and the complexity of the project are a source of significant business risk.

Lack of in house skills is another source of risk in the implementation of ERP systems. Lack of project team expertise has often been associated with software development risk (Anderson and Narasumhan, 1979; Barki, et al. 1993; Holland and Light, 1999; Jiang and Klein, 1999). An ERP system implementation project requires a wide range of skills (i.e., change management, risk management, BPR) in addition to technical implementation knowledge (Davenport, 2000; Glover et al., 1999). Organizations often lack change management skills and BPR skills required for an ERP system implementation. Further, an ERP system is often based on programming languages and concepts that are most likely new to existing IT staff (Kay, 1999). Thus, a lack of in house skills required for the ERP system implementation is a potential business risk.

When an organization moves to a complex ERP system environment, it faces many changes in staff relationships. Employees may need to create new working relationships, share information among departments, acquire new skills and assume additional responsibilities (Appleton, 1999). These changes can lead to resistance, confusion, and fear among users of the new system (Glover et al., 1999). Unwilling users increase implementation risk (Anderson and Narasumhan, 1979). Staff turnover and other types of users' resistance create additional business risks associated with an ERP system implementation.

In summary, based on a review of the ERP literature, there are five major business risks associated with the implementation of ERP systems: the lack of alignment of the new information system and business processes; the possible loss of control due to decentralization of decision making; risks associated with project complexity; the potential lack of in house skills; and users' resistance.

We next examine each of the above risks in more detail and specify controls that can be utilized by organizations to minimize that risk. 


\section{ERP IMPLEMENTATION CONTROLS}

\subsection{Lack of Alignment of the ERP system and business processes}

In order to minimize the risk associated with a lack of alignment of the ERP system and business processes, organizations engage in Business Process Reengineering (BPR), develop detailed requirements specifications, conduct system testing prior to the ERP system implementation and closely monitor system performance.

First, the rethinking and radical redesign of business processes (Hammer and Champy, 1993) enables an organization's operational processes to be aligned with an ERP system and allows an organization to better obtain the full benefits offered by the ERP system. It also results in the ERP implementation originating as a business initiative. Further, strategic clarity as well as constancy of purpose is attained (Davenport, 2000). Second, a detailed requirements specification for ERP selection increases the probability that the ERP system will meet the organization's system requirements and support the required operational processes. While the detailed planning is occurring, baseline metrics on current processes can be obtained what are requisite for the evaluation of the project's outcomes (Davenport, 2000). Third, system testing prior to system implementation and monitoring of the system after implementation are seen as critical to ensure that the ERP system operates smoothly and is able to provide adequate support for the organization's operational processes (Callaway, 1997; Davenport, 2000).

Thus, in order to minimize risks associated with a lack of alignment of the ERP system and business processes, an organization should reengineer business processes, develop a detailed requirements specification, conduct system testing prior to the system implementation and closely monitor the system's performance.

\subsection{Loss of Control due to decentralization of decision making}

Through the formulation of a steering committee, appointment of a project sponsor, and internal audit involvement, an organization could minimize the loss of control associated with decentralization of decision-making.

A steering committee enables senior management to directly monitor the project team's decision-making processes by having ratification and approval rights on all significant decisions, thereby ensuring that there are adequate controls over the project team's decision-making processes (Davenport, 2000; Whitten and Bentley, 1998). In addition to the formulation of a steering committee, a project sponsor is assigned direct responsibility for the ERP project's progress and often is responsible 
to secure funding (especially when more funds are needed than originally budgeted). The project sponsor is directly accountable for the project (Davenport, 2000; Whitten and Bentley, 1998). Internal audit's involvement in the ERP system implementation also helps ensure the adequacy of controls and that all parties are performing the appropriate tasks in a timely manner. Internal audit has extensive knowledge about the organization's control environment, business operational process and weakness existing in the current internal control system, which may not be available to the project team, managers and external auditors (Glover et al., 1999). Glover et al. (1999) argued that internal audit should be involved in an ERP system implementation early rather than later. They suggested that, at a minimum, auditors should stay informed throughout the system implementation process. This would enable internal audit to be aware of the changes due to the new system and to adjust the audit program accordingly.

In summary, through the formulation of the steering committee, appointment of a project sponsor, and internal audit's involvement the organization would minimize the business risks associated with possible loss of control resulting from the ERP system implementation.

\subsection{Project complexity}

The minimization of the risks associated with project complexity largely depends upon the formulation of a steering committee, senior managers' support, appointment of a project sponsor, the development of a detailed implementation plan, project management, a project team with adequate skills, and involvement by both consultants and internal audit.

First, in ERP system implementation projects, senior managers are often involved through appointment to a steering committee (Cameron and Meyer, 1998; Clemons, 1998; Davenport, 2000). Senior management's direct involvement in the system implementation project often increases the projects perceived importance within the organization (Raghunathan and Raghunathan, 1998) which encourages employees, system users and the IT department to be actively involved in, and provide support for, the ERP system implementation. Senior management commitment is needed because of the organizational changes that result from the implementation of ERP systems (Bingi et al., 1999; Davenport, 2000; Holland and Light, 1999). Second, by appointing an executive-level individual with extensive knowledge of the organization's operational processes to be the project sponsor, senior management is better able to monitor the ERP system implementation. The project sponsor has direct responsibility for and is held accountable for the project outcome (see, for example, (Cameron and Meyer, 1998; Clemons, 1998; Davenport, 2000)). The appointment of the project sponsor ensures that adequate accountability exists thereby reducing project risk. Third, in order to 
retain control over the project, many organizations develop a detailed system implementation plan that provides direction for the project team by setting out the project goals and targets (Davenport, 2000; Deutsch, 1998). The detailed system implementation plan (which includes performance metrics for subsequent evaluation) assists in the identification of potential risks resulting from identified delays in a timely manner (Bingi et al., 1999; Deutsch, 1998; Holland and Light, 1999). Fourth, the detailed requirements specification forces the organization to identify, up front, the project specifics and understand the level of complexity associated with the project. Fifth, strong project management is crucial to the success of any large endeavor, and this is especially so in ERP implementation projects that can span several years and cost millions of dollars (Davenport, 2000). Sixth, identification of the skills and knowledge of the project team is important, as is the employment of consultants to provide expertise in areas where team members lack knowledge (Barki, et al. 1993; Cameron and Meyer, 1998; Clemons, 1998). Seventh, it is critical for the project team and consultant to be assigned to the project on full time basis (and have a separate office for the ERP project), thereby ensuring they can focus completely on the project (Deutsch, 1998). Finally, internal audit's involvement is also vital for identification of the potential project risks, managing the risks and ensuring the effectiveness of the internal controls. All of these types of controls are important in minimizing the risks associated with project complexity.

In summary, the minimization of business risks associated with project complexity largely depend upon the formulation of the steering committee, senior managers' support, appointment of a project sponsor, a detailed requirements specification, development of a detailed implementation plan, a project team possessing adequate skills, involvement of the consultants and internal audit.

\subsection{Lack of in house skills}

Consultants are able to use their previous ERP systems implementation experiences; consequently, they can act as knowledge providers who lower the knowledge deficiency existing within organizations (Arens and Loebbecke, 1997). An organization, however, cannot completely rely on consultants to implement an ERP system, as consultants have limited specific knowledge of the organization's operations. Thus, a close working relationship between consultants and the organization's project team can lead to a valuable skill transfer in both directions (Bowen, 1998). Additionally, training that is available through the consultants, the vendor, or through some third party provides a valuable resource to develop skills that are lacking in-house. These controls seen as important in minimizing the risks associated with a potential lack of in house skills. Often times a new group, "super users" is created during the ERP implementation. These individuals 
acquire knowledge of the new detailed business process and also technical system knowledge through their implementation activities and training they receive (Davenport, 2000).

The external consultant's involvement in the ERP system project, the establishment of a close working relationship between the consultant and project team, and adequate training are critical factors in overcoming the business risks associated with the lack of in-house skills.

\subsection{Users' resistance}

User resistance has been associated with most any type of systems change, and even more so for ERP projects that are combined with BPR (since the users are worried that their job may at worst be eliminated, or at best be changed from their "usual" way of doing things). Workers who are reengineered out of a position and are subsequently redeployed within the company may enter a grieving process resulting in low productivity (Arnold, et al., 2000). Consequently, organizations often implement some risk management strategies to minimize users' resistance.

Appleton (Appleton, 1999) argued that managers' soft skills (such as communication and team building skills) are among the most important skills required for a successful ERP implementation. Users' involvement in the ERP project was also identified as important to gain the users "buy in" for the project (see, for example, (Cameron and Meyer, 1998; Clemons, 1998)). Involving users in the project enables the project team to be aware of users' requirements and address users' concerns (Best, 1997). In addition to involvement, user training enables users to acquire the requisite skills to utilize the ERP system.

To ensure that users are aware of the impact the ERP project will have on their responsibilities, many organizations develop a communication plan, and issue regular reports to keep users informed (Cameron and Meyer, 1998). Finally, when users perceive that top management really supports a particular project (and is willing to provide adequate resources), they will have a higher level of acceptance for that project. These types of controls, managerial soft skills, users' involvement, training, top management support, and communication are important in mitigating the business risks associated with possible user resistance.

In summary, the ERP implementation risks and their associated controls are shown in Table 1. The marked columns indicate when the control is applicable for minimizing the implementation risk. In the next section we present a case study of how a specific organization implemented various controls to minimize the business risks associated with for the implementation of an ERP package. 


\section{THE CASE STUDY}

\subsection{Data Collection}

The case study used in this research was the implementation project of a university's New Financial Management System (NFMS). The project provided a rich setting for the investigation of an ERP system implementation and its interaction with various organizational factors. In order to gain an in-depth understanding of the NFMS project, multiple data collection methods, including interviews, survey and archival data sources were used in this study.

\begin{tabular}{|c|c|c|c|c|c|}
\hline Risks & $\begin{array}{l}\text { Lack of } \\
\text { Alignment } \\
\text { Between IS } \\
\text { and Business } \\
\text { Processes }\end{array}$ & $\begin{array}{l}\text { Loss of Control } \\
\text { Due to } \\
\text { Decentralized } \\
\text { Decision- } \\
\text { Making }\end{array}$ & $\begin{array}{l}\text { Project } \\
\text { Complexity and } \\
\text { Mis-management } \\
\text { of Complex } \\
\text { Projects }\end{array}$ & $\begin{array}{l}\text { Lack of } \\
\text { In- House } \\
\text { Skills }\end{array}$ & $\begin{array}{l}\text { Users' } \\
\text { Resistance }\end{array}$ \\
\hline Business process reengineering & $\mathrm{X}$ & & & & \\
\hline Consultants' involvement & & & $\mathrm{X}$ & $\mathrm{X}$ & \\
\hline $\begin{array}{l}\text { The close working relationship } \\
\text { between the project team } \\
\text { and consultants }\end{array}$ & & & & $\mathrm{X}$ & \\
\hline Senior managements' support & & $\mathrm{X}$ & $\mathrm{X}$ & & $X$ \\
\hline Project sponsor & & $\mathrm{X}$ & $\mathrm{X}$ & & \\
\hline Steering committee & & $\mathrm{X}$ & $\mathrm{X}$ & & \\
\hline The project team & & & $\mathrm{X}$ & & \\
\hline $\begin{array}{l}\text { Detailed requirements } \\
\text { specification }\end{array}$ & $\mathrm{X}$ & & $\mathrm{X}$ & & \\
\hline Detailed implementation plan & & & $\mathrm{X}$ & & \\
\hline $\begin{array}{l}\text { Frequent communication with } \\
\text { the system users }\end{array}$ & & & & & $\mathrm{X}$ \\
\hline Managerial "People" skills & & & & & $\mathrm{X}$ \\
\hline Users involvement & & & & & $\mathrm{X}$ \\
\hline Training & & & & $\mathrm{X}$ & $\mathrm{X}$ \\
\hline Internal audit's involvement & & $\mathrm{X}$ & $\mathrm{X}$ & & \\
\hline $\begin{array}{l}\text { System testing prior to the } \\
\text { system implementation }\end{array}$ & $\mathrm{X}$ & & & & \\
\hline $\begin{array}{l}\text { Close monitoring the system } \\
\text { after the system implementation }\end{array}$ & $X$ & & & & \\
\hline Project management & & $\mathrm{X}$ & $\mathrm{X}$ & & \\
\hline
\end{tabular}

Note: The controls that are italicised are not associated with traditional systems implementations.

Table 1. ERP Implementation Risks and Associated Controls 
Four interview sessions were conducted: (1) the Director of Financial Services and the Business Analyst; (2) the Systems Analyst and the Information Technology Services (ITS) manager; (3) the Consultant; and (4) the Internal Auditor. The Director of Financial Services, the Business Analyst, the Systems Analyst and ITS manager are senior employees of the university. The Consultant was from a Big-Five consulting firm. The university outsourced its internal audit services to a different Big-Five accounting firm, and the senior internal auditor (a Director in that Big-Five firm who was involved in auditing the NFMS) participated in the study.

Prior to each interview an interview script was developed, which allowed a semi-structured data gathering technique with sufficient flexibility to pursue interesting information when disclosed by the participant. Additionally, an information sheet and an interview agenda (the interview script in bullet point) were sent to each participant prior to each interview. This allowed each participant to focus in advance on the issues and activities performed during the NFMS project. In order to attempt to control for possible collaboration among interviewees internal to the university, the first two interview sessions were scheduled within one day of each other and the interview agenda sent no more than twenty-four hours prior to each interview.

The interview scripts for sessions with the Director of Financial Services and the Business Analyst, the Systems Analyst and the ITS Manager, and the Consultant were based on archival information provided by the University and the risks and controls identified in the literature. The interview script for the session with the internal auditor was based on both the survey response from the internal auditor (see below) and archival sources. Some questions were asked to multiple interview groups to determine whether differences in opinions and perceptions existed among those groups.

The interview with the Director of Financial Services and the Business Analyst focused on project initiation, sponsorship, management, what they would do differently (the same), project issues and perceived success. The interview with the ITS Manager and the Systems Analyst focused on technical IT issues associated with the NFMS installation, communication, what they would do differently (the same), project issues, and perceived success. The interview with the Consultant focused on the consultant's role, the critical success factors and controls within the project and the perceived project risks. The interview with the internal auditor focused on the involvement of internal audit in the project, the perceived project risks, what the internal auditor would have done differently (the same), and the 
perception of the project's success. All participants agreed at the start of the interview to allow the session to be (audio) taped. The participants were also informed that they may stop the tape at any point during the interview (none did).

In addition to a scripted interview form, a questionnaire was developed and sent to the internal auditor 14 days before the interview and returned within 7 days. The objective of the questionnaire was to obtain more detailed information than would normally be possible during the interview. As compared to the interviews with the other groups, it was decided that a questionnaire was required before the interview of the internal auditor due to the technical nature of the questions on risk assessment and audit. The questionnaire was broadly based on a questionnaire developed by the Institute of Internal Auditors-United States, which appeared on their web site (http://www.theiia.org/survevr.htm, 16 February 1999). The questionnaire was adapted to the university environment and pilot tested with two experts in auditing - an academic and a partner in a major accounting firm. The questionnaire was revised as a result of the pilot test before being sent to the internal auditor.

The university web site was accessed for archival data dealing with the NFMS project. Also, the Director of Financial Services provided copies of all internal reports that were provided to the steering committee and copies of other documents associated with the project. This information served to provide additional background and richness, clarified concepts to be introduced during the interviews, and provided additional quantitative data that helped improve the understanding of the processes employed in this setting.

\subsection{Case Setting}

In the late 1980 s, the university had installed a packaged financial software Old Financial Management System (OFMS). The software was heavily customized to meet the specific needs of the university. During the 1990s, it became apparent that the OFMS was no longer able to meet the university's requirements. Feedback from users indicated that the OFMS did not provide timely and accurate information; in addition, it was user unfriendly (character rather than windowsbased) and provided low quality reports. Moreover, the OFMS was unable to be integrated with any other information systems operated within the university, and it was unable to handle the increasingly complex and evolving university organizational structure.

Under funding pressure, the university's administration searched for alternatives to improve operational efficiency. Additionally, in 1996 the Information Technology Services (ITS) division undertook a preliminary Year 2000 (Y2K) 
evaluation of the university's administrative systems. As a result of this review process, the OFMS was identified as one of the most critical Y2K problem areas. Due to the potential technical difficulties and the significant costs associated with upgrading the OFMS software, the university decided to replace it.

The senior management of the university decided that the NFMS project presented an opportunity to review and significantly re-engineer the financial operational processes to improve efficiency. The directive associated with the financial operational process review and redesign was to:

- further decentralize and devolve the financial management responsibility and financial transaction processing functions to each individual school and division level;

- restructure of all central financial management functions under one head and redefine the role of the Financial Services Division towards client services and decision support;

- review workflows, redesign and eliminate non-value added activities associated with the processing of financial information, and simplify the financial operational processes;

- implement the NFMS, with the resultant elimination of paper flows, provision of client/server and graphical user interface technology, and improvement of responsiveness to the end users.

In February 1997, the requirements documentation was approved by the NFMS steering committee, which consisted of the university's senior management. In March 1997, the university tendered for the NFMS and six responses were received. The tenders were evaluated against detailed system selection criteria that had been developed by the project team and approved by the Steering Committee.

After the evaluation of the tenders, a short list of two products remained. The subsequent evaluation of both products emphasized product suitability, implementation cost and strategy, the product's ability to change the university's financial operational processes; its capability for paperless systems and electronic transaction generation; PC and Macintosh support; and the potential consultancy arrangement.

In August 1997, the university awarded the contract to a "Big Five" consulting firm who proposed the installation of the current version of an ERP package. In addition, the consulting firm also agreed to provide implementation support, ongoing consultancy support and to organize the training sessions for the project team and system users.

After the system selection decision was made, the Director of Financial Services selected the NFMS project team members, consisting of: 
Director of Financial Services

(Project Team Leader) ${ }^{1}$

Business Analyst

Senior Analyst Programmer

Consultant (Project Manager)
Information Technology Services Manager

Accountant

Systems Analyst

The Vice-president for Finance and Operations was appointed as the project sponsor. Along with primary oversight responsibility, the project sponsor was also responsible for the project funding.

The first phase of the project was an analysis of current business practices (an "as is" analysis). This was followed by a "could be" analysis in which all the operational constraints were removed and business process reengineering was conducted. The last analysis conducted was a "to be" analysis in which the "could be" analysis was combined with the capability of the unmodified ERP software to arrive at what the operational processes would be modified.

It was planned to take two to three years to complete the project with the implementation of the NFMS scheduled for September 1998, along with progressive transition to the new financial operating and reporting process through 1998 to 1999 . Overall, the project team spent 12 months to complete the business process review and redesign, and a further 6 months to complete the implementation the ERP system.

At the NFMS project planning stage, the internal auditor was identified as a NFMS project stakeholder and was invited to the project meeting in November 1997. However, the internal auditor was not involved in an oversight role in the NFMS project until June 1998 when the project started to encounter delays in the planned schedule. From June 1998 until the completion of the project, the internal auditor provided several types of assurances about NFMS project. First, monthly quality assurance reports relating to the project were made to the steering committee. Second, the internal auditor evaluated the adequacy of the internal control procedures in the NFMS. Prior to the system implementation, the project team members "walked through" the NFMS with the internal auditor. Finally, the internal auditor continually performed risk assessment throughout the life of the NFMS and after the system was implemented. After the internal auditor was involved, actionable items that were the responsibility of the consulting firm dropped from items over three months old to only current month actionable items.

\footnotetext{
1 For expositional purposes the director of Financial Services will be referred to as the Project Team Leader. He was also the co-project manager on the NFMS with a representative from the Consulting firm. The Consulting firm representative will be referred to as the Project Manager.
} 
Training sessions were held so that the NFMS operatives and users could acquire the skills and knowledge required for operating the new NFMS. Given the different needs of the user groups, the training sessions were separated into general accounting and financial management training; NFMS "hand on" training; NFMS reporting training; technical training; and system administration training.

The NFMS was implemented in January 1999, having experienced a threemonth delay. The project manager and senior managers of the university were generally satisfied with the NFMS project. As a consequence of the NFMS implementation, the financial transaction processing responsibilities were devolved to each individual school and division level. The university's financial policies are now designed to eliminate the paper-intensive and labor intensive operational processes of the past, and are sensitive to the needs of the end users.

\section{RESULTS}

The controls used by the university are shown in Table 2, and are compared to the controls identified in the literature. These controls, discussed below, were identified by the interviewees (without prompting from the researchers) as critical to ensure that the risks associated with the project were minimized. Consistent with the ERP system implementation controls identified from the literature (see section IV above), the interviewees suggested that BPR; the project team members' skills and knowledge; the consultant's involvement; post implementation review; internal auditor's involvement; formulation of the steering committee; managerial "people" skills; and training sessions were vital to minimize risks perceived to be associated with the NFMS project. All the critical controls identified in the literature and the associated minimization of business risks were relevant for the NFMS project success. The interviewees, however, also identified, the change management skills and the in-depth project planning as vital for minimizing the risk of lack of success with the NFMS project.

The consultant believed that project ownership by the users was a vital in order for the project to gain the users' support and acceptance. The consultant emphasized the importance of the "ownership" of the system by stating "When you deliver the system to the users, if someone doesn't have the ownership of the system, they are not going to touch it. So really, it doesn't matter what you designed. You really need to build the ownership." As a result, users' were pro-actively involved in the project by joining various working parties and participating in training sessions and surveys. Prior to system implementation, training sessions were held for all the NFMS operatives to ensure they acquired the skills needed to operate the NFMS. 
While consistent with the literature, the need for project management skills became salient in this case setting and was vividly recalled by all participants. Midway through the project, the consulting organization reduced the Project Manager's hours on the job to approximately 8-12 hours per week. At that point in time, the Project Team Leader tried to compensate and take over the project management role. Unfortunately, the Project Team Leader also had day-to-day university activities that precluded full time project management activities. Additionally, the Project Team Leader did not have the same depth of project management skills as the consultant. It was at this time that the project Critical ERP system implementation controls identified in the literature

\begin{tabular}{|c|c|}
\hline Business process reengineering & Business processes reengineering \\
\hline Consultants' involvement & Consultants' involvement \\
\hline $\begin{array}{l}\text { Close working relationship between the project } \\
\text { team and consultant }\end{array}$ & $\begin{array}{l}\text { Close working relationship between the } \\
\text { project team and consultant }\end{array}$ \\
\hline Senior management support & Senior management support \\
\hline Project sponsor & Project sponsor \\
\hline Steering committee & Steering committee \\
\hline $\begin{array}{l}\text { Project team: } \\
\text { - members' skills and knowledge } \\
\text { - dedication of team members }\end{array}$ & $\begin{array}{l}\text { Project team: } \\
\text { - members' skills and knowledge } \\
\text { - dedication of team members }\end{array}$ \\
\hline Detailed requirements specification & Detailed requirements evaluation \\
\hline Detailed implementation plan & Detailed implementation plan \\
\hline Frequent communication & Frequent communication \\
\hline Managerial "people" skills & Managerial "people" skills \\
\hline Users' involvement & Users' involvement \\
\hline Training & Training \\
\hline Internal auditor's involvement & Internal auditor's involvement \\
\hline System testing prior to the system implementation & System testing prior to the system implementation \\
\hline Post implementation review & Post implementation review \\
\hline \multirow[t]{4}{*}{ Project management } & Project management skills \\
\hline & Users' project ownership \\
\hline & $\begin{array}{l}\text { Change management and transition } \\
\text { management }\end{array}$ \\
\hline & In-depth up front project planning \\
\hline
\end{tabular}

Note: The italicised items are not associated with traditional systems implementations, and the embolden items were identified in the case study.

Table 2. Comparison of the critical ERP system implementation controls

\section{Critical NFMS project controls identified by interviewees}

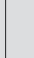


Detailed user procedure manuals were distributed and a help desk was established to provide direct assistance for the NFMS operatives. Two-way communication channels were also established between the system users and project team thereby ensuring the project team was aware of the users' requirements. By having a sense of project ownership, it was easier to gain the user's acceptance for the changes associated with NFMS project. Although the literature recognizes the importance of managerial "people" skills, users' involvement, training, frequent communication and users acceptance for the success of the ERP system implementation, the literature failed to identify the importance of ownership by the users, especially as it was expressed by all the parties involved in this implementation.

Similarly, the literature acknowledges the importance of managerial skills; however, the various types of project management skills that are critical to minimize risks in an ERP system implementation were not identified. During interview sessions, the interviewees identified a range of project management skills, in particular, change management skills, as vital to reducing the business risks associated with the NFMS project.

Due to the scope of the NFMS project and risks involved, in-depth project planning was identified by the consultant as critical for the success of NFMS. If more detailed in-depth project planning had been conducted by the NFMS project team, the consultant argued that many NFMS project risks would have been identified at an earlier stage of the project. The reviewed literature failed to identify the importance of in-depth up front project planning.

The consultants and project team worked closely and held regularly weekly meetings where the comprehensive meeting minutes and action items were recorded in a Lotus Notes database. Those meetings were identified as "crucial to success" of the project by all the parties involved in the project; it enabled the team member to identify problems in a timely manner. All the university staff involved in the NFMS project had access to the Lotus Notes databases. The project team members felt that "it was pretty easy to see when we were falling behind and needed more resources" through looking at the Lotus Notes databases. In addition to the Lotus Notes databases, the NFMS newsletter was issued on a monthly basis to keep the university staff reasonably informed about the project progress. This latter item was one way that user resistance was mitigated along with building a sense of ownership. The Lotus Notes database also fostered the creation of a knowledge base of all design and implementation activities, including documenting why certain design choices were made.

Due to a bad experience the university previously had with system customization, the NFMS project sponsor decided to implement the ERP system with a minimum amount of customization - " the university would bend itself to 
meet the needs of the system rather than bend the system to meet the needs of the university". Consequently, the university's operational processes were redesigned to fit with the ERP system. The university realized that BPR was essential to obtain the full benefits from the ERP system. When asked, the project team leader responded that BPR and ERP were inexplicably intertwined, "A significant part of the project is reviewing the way our business process currently operates and identifying opportunities to improve them. Having identified them, we want to use the NFMS as tool to implement them". Similarly, the consultant highlighted the essence of the NFMS project by suggesting:

"The system implementation was the one doing the driving. That was where the major control and the major sponsorship came through, because that was what the project was all about, but it is underpinned by the process redesign, the financial and the NFMS operative role, and was underpinned by the management of change or change project."

All the controls identified as critical in the literature were found in this case study. Further, several controls that have not been previously addressed were identified (see Table 2).

\section{CONCLUDING THOUGHTS}

The purpose of this study was to identify the risks and controls related to the implementation of ERP systems in organizations. The extant literature on ERP systems and the literature on systems development risks were used to investigate the risks and controls related to the successful implementation of an ERP system in a case study of an organization. The case study provided support for risks and controls identified in the literature. It also allowed for the identification of several new controls. An expanded model of risks and controls appears as Table 3 . The newly identified controls have an effect on all risk areas.

An ERP implementation project is different from other systems development projects. The prior literature had identified significant risk factors that included technological change, organizational change and project complexity. These factors are the hallmarks of most (if not all) ERP implementations. Consequently, it is important to understand how these risk factors can be mitigated. In this research, controls required to minimize five types of risks that organizations must control in an ERP system implementation were identified. The results of this research provide support for the proposition that the success of an ERP system implementation is dependent, in the first instance, on identifying the major business risks and the controls that need to be put in place to minimize those risks. 


\begin{tabular}{|c|c|c|c|c|c|}
\hline Risks & $\begin{array}{l}\text { Lack of } \\
\text { Alignment } \\
\text { Between IS } \\
\text { and Business } \\
\text { Processes }\end{array}$ & $\begin{array}{l}\text { Loss of Control } \\
\text { Due to } \\
\text { Decentralized } \\
\text { Decision- } \\
\text { Making }\end{array}$ & $\begin{array}{l}\text { Project } \\
\text { Complexity and } \\
\text { Management of } \\
\text { Complex } \\
\text { Projects }\end{array}$ & $\begin{array}{l}\text { Lack of } \\
\text { In-House } \\
\text { Skills }\end{array}$ & $\begin{array}{l}\text { Users' } \\
\text { Resistance }\end{array}$ \\
\hline Business process reengineering & $X$ & & & & \\
\hline Consultants' involvement & & & $\mathrm{X}$ & $\mathrm{X}$ & \\
\hline $\begin{array}{l}\text { The close working relationship } \\
\text { between the project team and } \\
\text { consultants }\end{array}$ & & & & X & \\
\hline Senior managements' support & & $X$ & $X$ & & $X$ \\
\hline Project sponsor & & $\mathrm{X}$ & $\mathrm{X}$ & & \\
\hline Steering committee & & $\mathrm{X}$ & $\mathrm{X}$ & & \\
\hline $\begin{array}{l}\text { The project team: } \\
\text { - members' skills and knowledge } \\
\text { - dedication of team members }\end{array}$ & & & $\mathrm{X}$ & & \\
\hline Detailed requirements specification & $X$ & & $X$ & & \\
\hline Detailed implementation plan & & & $\mathrm{X}$ & & \\
\hline $\begin{array}{l}\text { Frequent communication with the } \\
\text { system users }\end{array}$ & & & & & $\mathrm{X}$ \\
\hline Managerial "People" skills & & & & & $\mathrm{X}$ \\
\hline Users involvement & & & & & $\mathrm{X}$ \\
\hline Training & & & & $\mathrm{X}$ & $\mathrm{X}$ \\
\hline Internal audit's involvement & & $\mathrm{X}$ & $\mathrm{X}$ & & \\
\hline \multicolumn{6}{|l|}{ System testing prior to the system } \\
\hline implementation & $\mathrm{X}$ & & & & \\
\hline $\begin{array}{l}\text { Close monitoring the system after } \\
\text { the system implementation }\end{array}$ & $\mathrm{X}$ & & & & \\
\hline Project management skills & & $\mathrm{X}$ & $\mathrm{X}$ & & \\
\hline $\begin{array}{l}\text { Change management and transition } \\
\text { management }\end{array}$ & & X & $X$ & & $X$ \\
\hline Users' project ownership & & & & & $\mathrm{X}$ \\
\hline In-depth up front project planning & $\mathrm{X}$ & $\mathrm{X}$ & $\mathrm{X}$ & $\mathrm{X}$ & $\mathrm{X}$ \\
\hline
\end{tabular}

Note: The controls that are italicised are not associated with traditional systems implementations. The embolden items were identified in the case study.

Table 3. Expanded ERP Implementation Risks and Associated Controls

There are several limitations of this study. First, a case study research method was used to investigate a single site. Consequently, the limitations associated with the case study approach are applicable (Yin, 1994). Second, the investigation of the NFMS project was carried out shortly after the NFMS implementation. The research findings therefore reflect the interviewees' retrospective perceptions of the NFMS implementation. Interviewees may have had different views as to what were the critical controls and risks during the NFMS implementation project. Third, the university implemented the NFMS in January 1999 and this study was conducted between March and June 1999. Therefore, the results of this study are limited to the perceived short run success. Fourth, the NFMS was limited to the implementation of one module of, albeit, a major EPR package. 
Several avenues for future research result from this study. While the research findings provided additional evidence on risks and associated controls in an ERP implementation, further case studies would be valuable to gain an understanding as to whether these risks and controls exist across organizational settings. Second, future research can examine the correlation among the risks and controls identified in this study through a survey of organizations that implemented ERP systems. Third, longitudinal studies of ERP system implementations, and subsequent use in organizations, would provide evidence of the persistence of risks and controls.

Fourth, further work is needed on the contribution of business risks and associate controls to the success of implementing ERP systems. Finally, further research can examine the timing and extent of internal audit involvement in ERP system implementations.

\section{REFERENCES}

Arnold, V.; Hunton, J.E.; Sutton, S.G. (2000): “On the Death and Dying of Originality in the Workplace: A Critical View of Enterprise Resource Planning Systems' Impact on Workers and the Work Environment", Working Paper, University of South Florida.

Anderson, J.; Narasumhan, R. (1979): “Assessing Implementation Risk: A Technological Approach”, Management Science, vol.25, n.6: 512-521.

Appleton, E. (1999): “How to Survive ERP”, Datamation, March.

Arens, A.A.; Loebbecke, J.K. (1997): Auditing: An Integrated Approach. PrenticeHall. Upper Saddle River. NJ.

Attewell, P. (1992): “Technology Diffusion and Organisational Learning: The Case of Business Computing”, Organisation Science: 1-19.

Barki, H.; Rivard, S.; Talbot, J. (Fall 1993): "Toward an Assessment of Software Development Risk", Journal of Management Information Systems, vol.10, n.2: 203-225.

Best, C. (1997): "Integrated System Builds on Human Foundation", Computing Canada December, vol. 23.

Bingi, P.; Sharma, M.K.; Godla, J. (1999): "Critical Issues Affecting an ERP Implementation”, Information Systems Management, vol.16, n.3: 7-14.

Bowen, T.S. (1998): "Committing to Consultants: Outside Help Requires Internal Commitment and Management Skills", Info World.

Brockner, J.(1992): "The Escalation Of Commitment Towards A Failing Course Of Action: Towards Theoretical Progress", Academy of Management Review, vol.17, n.1: 39-61. 
Callaway, E. (1997): “ERP: Test for Success”, PC Week.

Cameron, D.P.; Meyer, L.S. (1998): "Rapid ERP Implementation - A Contradiction", Management Accounting (USA), vol.80.

Clemons, C. (1998): "Successful Implementation Of An Enterprise System: A Case Study", Proceedings of the AIS Conference Americans, Baltmore Maryland: 109-110.

Collett, S. (1999): "SAP: Whirlpool's rush to go live led to shipping snafus", Computerworld Online News: http://www.computerworld.com/cwi/story / 0,1199,NAV47_STO29365,00.html

Davenport, T.H. (July/August 1998): "Putting the Enterprise into the Enterprise System", Harvard Business Review, vol.76, n.4: 121-133.

Davenport, T.H. (2000): Mission Critical: Realizing The Promise Of Enterprise Systems. Harvard Business School Press. Boston, MA

Deutsch, C.H. (1998): "Some Tips On Avoiding the Pain", The New York Times. November 8.

Glover, S.M.; Prawitt, D.F.; Romney, M.B. (February 1999): "Implementing ERP”, Internal Auditor: 40-47.

Hammer, M. (July-August 1990): "Reengineering Work: Don't Automate, Obliterate", Harvard Business Review: 104-112.

Hammer, M.; Champy, J. (1993): Reengineering the Corporation: A Manifesto for Business Revolution. Harper Business. New York.

Holland, C.; Light, B.A. (1999): "Critical Success Factors Model For ERP Implementation", IEEE Software, vol.16, n.3: 30-36.

Jiang, J.J.; Klein, G. (1999): "Risks To Different Aspects of System Success", Information and Management, vol.36: 263-272.

Jiang, J.J.; Klein, G.; Balloun, J. (1996): "Ranking of System Implementation Success Factors", Project Management Journal, vol.27, n.4: 50-55.

Johnson, J. (1995): "The Dollar Drain of IT Project Failures", Application Development Trends, vol.2, n.1: 41-47.

Kanodia, C.; Bushman, R.; Dickhaut, J. (1989): "Escalation Errors and the Sunk Cost Effect: An Explanation Based on Reputation and Information Asymmetries", Journal of Accounting Research, vol.27, n.1: 59-77.

Kay, E. (1999): "Desperately Seeking SAP Support”, Datamation, March.

Keil, M. (1995): "Pulling The Plug: Software Project Management And The Problem Of Project Escalation”, MIS Quarterly, vol.19, n.4: 421-447. 
Martin, M.H. (1998): “An ERP Strategy”, Fortune, 2 February: 95-97.

McFarlan, F.W. (1981): "Portfolio Approach to Information Systems", Harvard Business Review, vol.59, n.5: 142-150.

McGeever, C. (1999): “GoreTex maker files suit over software installation”, Computerworld Online News, http://www.computerworld.com/cwi/story / 0,1199,NAV47_STO29312,00.html

McKie S. (1998): “Packaged Solution or Pandora’s Box?", Intelligent Enterprise, November: 39-43.

Olsen, F. (1999): “Delays, Bugs, and Cost Overruns Plague PeopleSoft's Services", The Chronicle of Higher Education, 24 September: A32, A33-34, A36.

Olsen, F. (2000): "PeopleSoft Problems Persist, Cleveland State Looks for a New Project Manager", The Chronicle of Higher Education, 4 February: A49.

Raghunathan, B.; Raghunathan, T.S. (1998): "Impact of Top Management Support on IS Planning”, Journal of Information Systems, vol.12, n.1: 15-23.

Reel, J. (1999): “Critical Success Factors in Software Projects", IEEE Software, vol.16, n.3: 18-33.

Scott. J. (1999): “The FoxMeyer Drugs' Bankruptcy: Was it a Failure of ERP?", Proceedings of AMCIS 1999 Americas Conference on Information Systems: 223-225.

Sharp, D.J.; Salter, S.B. (1997): "Project Escalation and Sunk Costs: A Test of The International Generalizability of Agency and Prospect Theories", Journal of International Business, vol.28, n.1: 101-122.

Staw, B. (1976): "Knee-Deep in the Big Muddy: A Study of Escalating Commitment to a Chosen Course of Action", Organizational Behavior and Human Performance, vol.16, n.1: 27-44.

Staw, B. (1981): "The Escalation of Commitment to a Course of Action", Academy of Management Review, vol.6, n.4: 577-587.

Staw, B.; Ross, J. (1987): "Behavior in Escalations Decisions: Antecedents, Prototypes, and Solutions", In Cummings, L.L.; Staw, B. (Eds): Research In Organizational Behavior. JAI Press. Greenwich, Conn.

Stedman, C. (1999): "ERP Project Leads to Court Fight", Computerworld http:// www.computerworld.com/cwi/story/0,1199,NAV47_STO36333,00.html

Whitten, J.L.; Bentley, L.D. (1998): Systems Analysis and Design Methods, 4th Edition. Irwin/McGraw-Hill. Boston, MA.

Yin, R.K. (1994): Case Study Research, Design and Methods (2 ${ }^{\text {nd }}$ Edition). Sage Publications

Zmud, R.W. (1980): "Management of Large Software Development Efforts", MIS Quarterly, vol.4, n.2: 45-55. 